\title{
An Overview of the Production Capacity and Operational Optimization in the Framework of Industry 4.0
}

\author{
Elif Ocakci ${ }^{1, *}, J \ddot{r g} \mathrm{Niemann}^{2}$, Caius Luminosu ${ }^{3}$, and Ilie Taucean ${ }^{3}$ \\ ${ }^{1}$ Continental Teves AG, Department of Strategy and Business Development, Guerickestraße 7, 60488 \\ Frankfurt am Main, Germany \\ ${ }^{2}$ Duesseldorf University of Applied Sciences, Faculty of Mechanical and Process Engineering, FliX \\ research Center for Life Cycle Excellence, Muensterstrasse 176, 40476 Duesseldorf, Germany \\ ${ }^{3}$ Politehnica University of Timisoara, Faculty of Management in Production and Transportation, 14 \\ Remus str., 300191 Timisoara, Romania
}

\begin{abstract}
Dynamic and volatile markets, triggered by increasing competition, rising product variety and many more factors, lead to a series of reactions: An increasing product complexity (e.g. a higher number of software components) shorter life cycles, faster development cycles and the call for a prompt market readiness. This has immense repercussions on the value chain and on the manufacturing sites. Additionally, it leads to interactions between product features and the production environment, which includes development, production, quality management, supply chain management and all other related disciplines.As an example, the average development time decreased within the last 20 years up to $20 \%$ (impact on research and development), while the product complexity steadily increased (impact on the product features). Until recently, activities based on information and communication technology (ICT) to address these profound challenges have been referred to as "Digitalization". However, to counteract the afore mentioned challenges in a more target-oriented manner, the German government introduced the strategic initiative 'Industry 4.0 '. It is crucial for companies to primarily perceive the options and content of Industry 4.0 for potential transformation from machine dominant production to digital manufacturing.
\end{abstract}

\section{Introduction and motivation for Industry 4.0}

Industrial companies are currently facing challenging times due to internationalization, growing competitiveness, changes in supplier and customer markets and innovation in technology [1-3]. The so-called digital transformation is progressing rapidly and uninterruptedly. The attack on what already exists has begun [4].

*Correspondingauthor:elif.ocakci@continental-corporation.com 
Since Konrad Zuse in 1941 took significant steps into the computer age and in 1950 around 8,000 worldwide Computer systems existed, today all areas of life are permeated with information and communication technology. The development of the mass market for broadband internet and the introduction of smartphones, tablets and wearables caused the number of networked objects to explode [5,6]. Digitization not only enables new intelligent products and new forms of internet-based services (so-called smart services), it also changes industrial production. The term Industry 4.0 stands for a new level of organization and Control of complex value creation structures [7]. Obviously, the industry is undergoing a profound change known as the fourth industrial revolution. Intelligent technology forms the basis for Industry 4.0 Systems that are networked with one another via the "Internet of Things". Of importance will be the intelligence of the systems, the adaptive, robust, predictive and will enable particularly user-friendly systems. Fascinating, unmanageable possibilities open for designing new business models and innovative value creation structures as part of future-oriented corporate management in the age of digitization. In sum, this shows that there is a great need for productivity-enhancing, but also flexibilitypromoting measures and approaches in the industry. Industry 4.0 is seen as one of the answers to these megatrends and the associated challenges. Therefore, it is not surprising, that according to a study the following key statements are made [9]:

- Industry 4.0 leads to a higher production and resource efficiency of $-18 \%$;

- Industry 4.0 enables new, often disruptive digital business models;

- Digitized production and services generate an additional $€ 30$ billion per year for the German economy;

- Digitization of the product and service portfolio is the key to sustainable Corporate success;

- Horizontal cooperation enables better fulfilment of customer requirements;

- Industry 4.0 transforms the entire company;

- The integrated analysis and use of data is the core capability within Industry 4.0.

\section{Concept of Industry 4.0}

In this chapter the concept of Industry 4.0 and its sub-concepts and technologies will be examined. However, the terms of concept and technology must first be distinguished from each other to get a deeper understanding. A concept is a piece of knowledge that serves to categorize objects and/or perceptions. It can also consist of several categories[10]. Technology, on the other hand, describes an application-oriented, universally valid relationship between purpose and means and offers resources that are intended to put scientific knowledge into practice [11].

In the context of production, the idea of Industry 4.0 is to establish a new way to organize value chains by means of new concepts and technologies [12]. The resulting potentials from this are immense. One example are self-organizing networks within production environments [13]. Consequently, Industry 4.0 is no unattached concept. It is much more a merger of several single concepts and technologies which require an interdisciplinary exchange at all levels.

Thereby, Industry 4.0 changes not only the traditional processes in the industry, it also allows for new business models [14].Therefore, German experts speak of a dual strategy when realizing Industry 4.0 [14]: (1) German industry should consistently develop innovative technologies and concepts to maintain a leading world market position, especially with regards to intelligent production approaches; (2) At the same time, new markets for technologies and products must be explored to distribute these technologies profitably. To succeed in that dual strategy, existing basic technologies and concepts must 
be adapted to the special features of production technology and in addition, innovative solutions for new markets must be researched [14].

\subsection{Emergehistory}

This chapter will merely point out the most important milestones. Industry 4.0 was and is a politically motivated attempt to spread the approach of Digitalization over the German manufacturing industry. The overall aim thereby is to maintain and augment the international competitiveness of the German industry [15].

In 2006, during the first national IT-summit, the guiding principle of Industry 4.0 was envisaged for the first time[16]. The term itself became public for the first time during the Hannover Fair ('Hannover Messe') in 2011. It was developed by the "Forschungsunion", a scientific advisory council of the German government [17]. In 2012 the industry associations BITKOM, VDMA and ZVEI established the Industry 4.0 Platform ("PlattformIndustrie 4.0") with the goal to coordinate future challenges cross-sectoral [18].

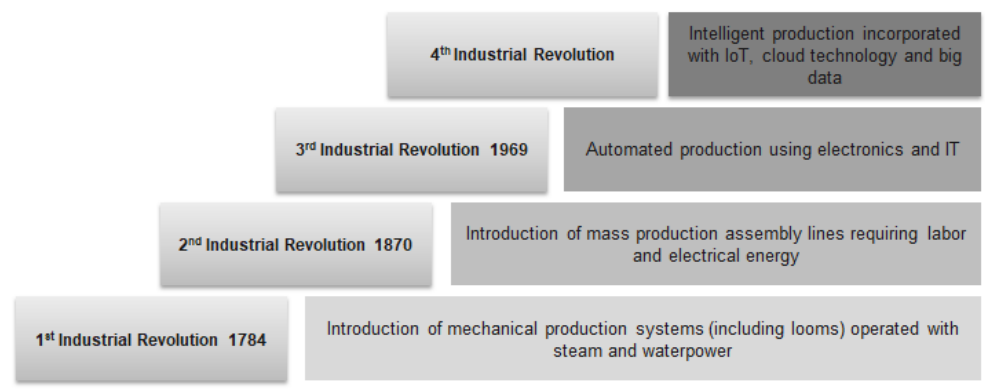

Fig.1. Historical perspective of industrial revolutions (reproduced with permission from [20] ).

In 2015 the German government took the lead over and created different task forces consisting of experts from industry and science [19]. The term Industry 4.0 was chosen, because it will initiate the fourth industrial revolution which focuses on the interconnectedness of the production elements. As Fig. 1 shows the first industrial revolution began with the creation of the first mechanical manufacturing system $\left(18^{\text {th }}\right.$ century), the second industrial revolution started with the mass production through assembly line work ( $19^{\text {th }}$ century) and the third industrial revolution commenced with the use of electronics and ICT to further develop production processes $\left(20^{\text {th }}\right.$ century) [14].

\subsection{Terminology delimitation}

The meaning of the term Industry 4.0 has different understandings in the literature, [21] though at the beginning this perception was even more indistinct. But by the time, a clearer understanding could be observed.

Because the term was additionally spread over to other business areas than production, such as services or business models, there is still a variety of definitions [18]. Fig.2 illustrates the relationship between some terms that are wrongly used as synonyms for Industry 4.0 . 


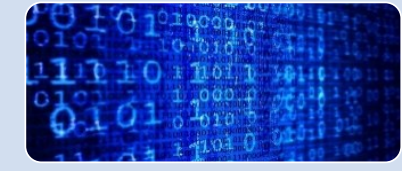

\section{Digitization}

- The process of making information available and accesigble in a digital format.

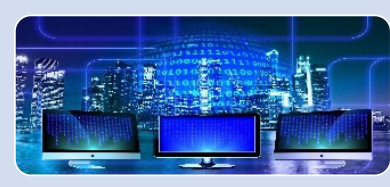

\section{Digitalization}

- The process of considering how best to apply digitized information to simply specific operations.



Digital Transformation

- The process of devising new business applications that integrate all the digitized data and digitalized applications.

Fig.2. Digitization, Digitalization and Digital Transformation in the Framework of Industry 4.0 (enhanced according to [51]).

The term Industry 4.0 is a collective term [22]. An initial literature review has shown that the term is often used synonymously for great amounts of other concepts and subconcepts. Along with Industry 4.0 terms such as Digitalization, Internet of Things, Smart Factory and many more are frequently mentioned.

However, this is just a small extract of the existing terms in literature. It is especially important to distinguish the terms Digitization, Digitalization, Digital Transformation, and Industry 4.0 at this point, because they act as collective terms and comprise concepts and technologies on a superficial level. The terms Digitization, Digitalization and Digital Transformation do not mean the very same thing. This becomes evident through the following definitions.

Firstly, Digitization is defined as "the process of changing from analog to digital form, also known as digital enablement. Said another way, Digitization takes an analog process and changes it to a digital form without any different-in-kind changes to the process itself" [23]. Secondly, Digitalization is defined as an approach"encompasses everything [...] that describes, examines and explains the impact of the use of IT and the penetration of technology and services in all areas of daily life, whether private or institutional" [25]. Thirdly, Digital Transformation is defined as "the purpose of the digital transformation is to improve the process efficiency of business activities. Digital transformation is the further development of stand-alone solutions for company-wide networking to support all valueadding corporate activities to realize process cost reductions" [23].

These definitions are only an extract of the widespread use of the terms. Therefore, it is important to know that Digitization, Digitalization and Digital Transformation are not restrictively utilized in the literature [25]. Some other definitions for instance include also the more general topics changing and responsibility [26]. It also becomes apparent that the definitions are not the same, but very unidirectional; it can be said that information will be digitized, processes will be digitalized, and the business and its strategy will be digitally transformed [27].

In general, Industry 4.0 includes Digitization, Digitalization and Digital Transformation with respect to production environments. However, due to the different understandings which exist, the Industry 4.0 Platform established a vague definition for the term Industry 4.0. As mentioned before, it is not the only definition, but it is the official definition of the German government. "Industry 4.0 refers to the intelligent networking of machines and processes for industry with the help of information and communication technology" [28]. This definition focuses on the intelligent networking of elements of the production and other processes using ICT. 
A more detailed definition is given by Acatech, a scientific academy which advises the German government. They take up the same definition and explicate it in more depth [29]. "Industry 4.0 basically means the technical integration of Cyber Physical Systems into production and logistics as well as the application of the Internet of Things and Services in industrial processes, including the resulting consequences for value creation, business models and downstream processes, services and work organization" [14]. This means that Industry 4.0 focuses on the complete digital networking of the industrial value chain [30].

Besides the mentioned application components, there are also many others mentioned, such as Big Data Analytics. However, these are not considered as independent components of Industry 4.0 [12]. Therefore, the main components of Industry 4.0 are Cyber Physical Systems which will be supported by many other components and applied in Smart Factories. The description of that takes place in the following chapters.

It should be noted that the reshaping of the manufacturing industry is also being pursued by other nations. However, the various research initiatives, for instance in the USA ('Advanced Manufacturing') and China ('Made in China 2025'), see the transformation described in Industry 4.0 only as one trend among many [31].

\section{Production Capacity and Operational Optimization}

\subsection{Production systems}

Production systems focus on the management of production environments in order to achieve the business objectives. Therefore, the entire value chain will be considered, from supplier to the customer. The input (e.g., knowledge, materials, financial resources and more) will be transformed during the value creation process (i.e., manufacturing) to an intermediate or end product. Associated processes such as transport or quality measures assist and sustain the manufacturing process. The propulsions for that are humans and technical resources like machines or IT-systems. The relation between the several elements of the production system is determined using adequate methods and therefore impinge on the process and structural organization [32].

The production system, defines what guidelines to follow when developing, implementing, and maintaining processes in the coherence of production. As a holistic system it will unfold its full effected when all elements and processes correlate [33,34]. In the future production systems will focus more on performance measurement by means of precise data and their connection.

Sensors will observe the entire production process, from incoming goods through manufacturing to shipping. The sensor data will be stored together with additional relevant data from other sources in a single data warehouse in order to connect them more easily. Thanks to that connectivity, fact-based, target-oriented decisions will be made and guesswork will be eliminated. Through the access to the comprehensive and topical information, reporting can be automatized and employees as well as leaders will be easily able to identify appropriate solutions and to take precise actions [35]. Fig.3 shows the improvement opportunities by categories [35].

Huge potential through new business models and increases in resource productivity and cross-value chain efficiencies are promised through Industry 4.0, according to [14]. Smart factories are going to be capable of profitably producing custom specific items in an agile way, and smart assistance systems will help workers to focus on value-added activities rather than routine tasks [7]. 


\begin{tabular}{|c|c|}
\hline Labor & Multifactor productivity \\
\hline $\begin{array}{l}\text { Increased supply and productivity } \\
\text { - Increased labor-force participation } \\
\text { Better and faster matching of workers with } \\
\text { employers } \\
\text { Increased productivity of workers in the labor } \\
\text { force }\end{array}$ & \multirow{3}{*}{$\begin{array}{l}\text { R\&D and product development } \\
\text { Better use of data leads to new inventions } \\
\text { Faster product development cycles } \\
\text { enabled by better testing and quality } \\
\text { control }\end{array}$} \\
\hline Capital & \\
\hline $\begin{array}{l}\text { Improved asset efficiency } \\
\text { Preventive maintenance decreases downtime } \\
\text { and reduces expenditure on maintenance } \\
\text { - Increased use of assets }\end{array}$ & \\
\hline
\end{tabular}

Fig.3. Improvement opportunities by categories (enhanced according to [52]). [1].

Fig. 4 gives a summary of the estimated cost optimization potential through Industry 4.0

\begin{tabular}{|c|c|c|}
\hline Cost Type & Effects & Potentials \\
\hline Inventory & $\begin{array}{l}\text { - } \quad \text { Reduction of safety stocks } \\
\text { - } \quad \text { Avoidance of Bullwhip and Burbridge effects }\end{array}$ & -30 to $-40 \%$ \\
\hline Production & $\begin{array}{l}\text { - Increase in Overall Equipment Effectiveness (OEE) } \\
\text { - Improcess control loops } \\
\text { - Iment in vertical and horizontal labor flexibility }\end{array}$ & -10 to $-20 \%$ \\
\hline Logistics & - Higher degree of automation (milk run, picking, ...) & -10 to $-20 \%$ \\
\hline Complexity & $\begin{array}{l}\text { - Enhanced span of control } \\
\text { - Reduced trouble shooting }\end{array}$ & -60 to $-70 \%$ \\
\hline Quality & - Real-time quality control loops & -10 to $-20 \%$ \\
\hline Maintenance & $\begin{array}{l}\text { - Optimization of spare part inventories } \\
\text { - Condition-based maintenance (process data, measurement } \\
\text { data) }\end{array}$ & -20 to $-30 \%$ \\
\hline
\end{tabular}

Fig.4. Estimated benefits of Industry 4.0 (enhanced according to [1] ).

\subsection{Flexibility and transformability}

Above all, companies in general are challenged by the need to steadily adjust the many elements of manufacturing environments and production systems [36]. Due to the influence of dynamic and volatile markets in the automotive industry, this can only be achieved by the development and utilization of specific methods, technologies, resources, and organizational structures.

The production environment must be able to react immediately, economically, and situationally on influencing factors. The key factor to this is the enabling of the production system and thus the production environment to more changeability. Since it is an attribute which facilitates the response capacity and velocity with minimal effort, it is very crucial to counter influence factors on the production environment [32]. However, there is no consistent use of terms in the literature.

In the research of Elkins, Huang, and Alden, for instance, use the term agile, but refer also to the overall issue of changeability [37]. Other authors, in turn, utilize other terms [32].

For convenience only, this work will follow the methodology presented by[38]. In the context of quality, changeability can refer to the ability of a production environment to adapt to new qualityinfluencing circumstances such as an increase in production volume. 
Since focused on the production level, the approach distinguished additionally five different degrees of changeability; two of them are flexibility and transformability [38]. Because the distinction of the three other terms has only a minor impact on this work, solely flexibility and transformability will be discussed subsequently. Transformability, however, should not be confused with flexibility. Flexibility enables a production environment to react on changes by using predefined measures which have predefined capacities and limits [39]. For instance, the capability to react on a supplier failure with predefined measures.

Where as transformability enables a production environment to counter divergencies with measures beyond the predefined set of measurements [40]. The divergencies can be bridged without defining the solution in advance [41]. Hence, transformability leads to the condition that solutions arise from the circumstances and the borders of capacities become flexible [32]. This leads to an efficient utilization of existing resources. Fig.5 shows the relationship between flexibility and transformability.

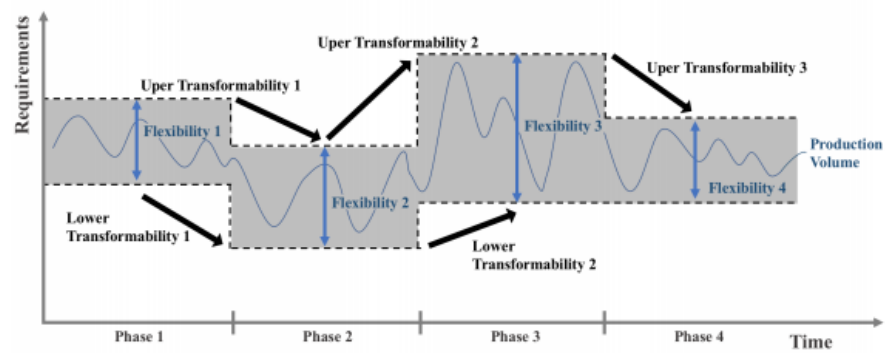

Fig.5. Difference between transformability and flexibility (enhanced according to [53] ).

Flexibility and transformability are independent from each other. Is a production environment defined to bridge divergencies flexibly and to a large extent, then - despite its inefficiency - the attribute of transformability becomes dispensable [32]. Production environments nowadays contain the component of flexibility but show a lack of transformability.

Considering the automotive industry, suppliers are often contractually forced to have a leeway to increase their output, in case another supplier of the same part/component failures to deliver timely. The use of new technologies, such as additive manufacturing or business analytics, would establish a transformable production environment which enable the anticipation of supplier failures and other divergencies. This is just one example of many. The literature offers a wide range of examples for projects in the automotive industry $[1,38]$.

\subsection{Transformation enablers}

In order to encounter the earlier mentioned challenges in the automotive industry, it becomes necessary to enable optimal response capacity of the production environment. In the literature there exists a larger number of transformation enablers [42-44]. Focusing on the production environment level, five main transformation enablers can be listed [38]. Fig. 6 shows them in the context of the production environment and the impacts on it.

The production environment is characterized by the methods and organizational structure, which are arranged by the production system. Input factors like manpower or machines will be transformed to output factors, such as products and services. That transformation process is impacted by internal and external factors like the earlier described challenges of the automotive industry. To encounter and react on these challenges, the transformation enablers are needed [45]. 
Universality describes the design and dimensioning of objects. The object thereby, fulfils from the beginning various requirements and can undertake different tasks without hinging on anything $[32,38]$. A common example is a machine which can process several different product variants or even whole units without being set up. Mobility is important to reconfigure (add/remove) objects. An object with this attribute has no spatial constraints. It can be moved without great effort, such as a machine with wheels $[32,38]$.

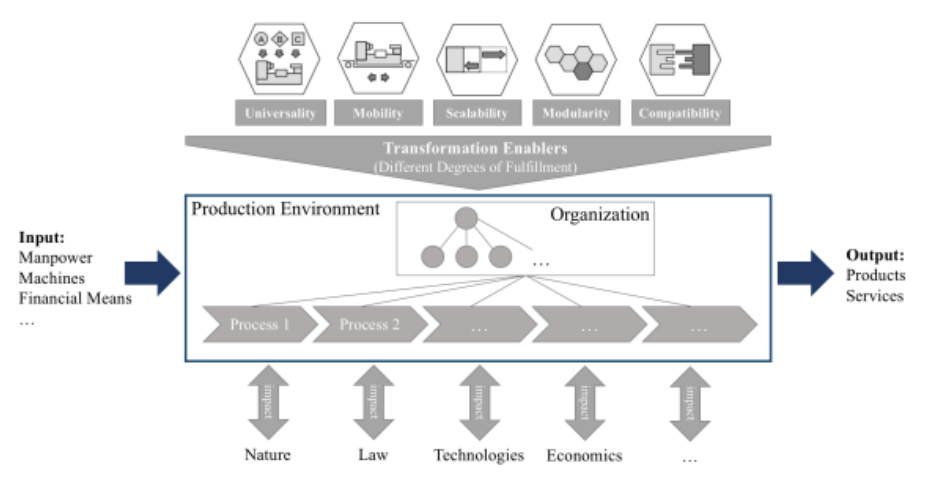

Fig.6. Influence of transformation enablers on the production environment (according to [38] ).

Scalability is the ability to scale something up or down. This can be related to technologies, humans, space, and many other things [32,38]. A non-physical example is the extending of the working time to use open capacities. An object or system which consist of several elements or functions which are independent from each other fulfils the requirement of modularity $[32,38]$. For instance, a removable robotic arm which is replaced by another one that fulfils the same technical standards. Compatibility enables objects internally and externally to network with other objects regarding materials, information, energy and many other things $[32,38]$.

A software with many standardized interfaces fulfils exactly that attribute. The difference between modularity and compatibility is that the former focuses on the exchange of modules while the latter enables the networking between two objects. Furthermore, these transformation enablers have different degrees [32]. A machine that can process a high number of different elements has a higher extent of universality than a machine with a low number of processable elements. In addition, not every enabler can be used in every case [38].

In the context of real estate, mobility is hardly not realizable. Furthermore, the enablers correlate. Often modular objects need also to fulfil the requirement of compatibility, so that the replacing module fits into the interface. Nowadays, many objects in the production environment fulfil these attributes partially. With the activities in the framework of Industry 4.0, available prerequisites will be used to develop the production environments with a holistic approach. This will contribute to hedging and enhancing the competitiveness of producing companies [36].

\section{Criticism and Conclusion}

A much-criticized point of Industry 4.0 is whether it is to be understood as a vision of futuristic value creation (i.e., a revolution) or as a mission to maintain German and European competitiveness (i.e., an evolution). However, in the end that is not important, because the debate about the revolutionary or evolutionary nature of the forthcoming 
development in the industrial environment does not change the fact that the current and steadily increasing challenges are present and can be tackled by the concepts and technologies of Industry 4.0 [46].

Furthermore, Industry 4.0 is based on the interaction of a wide variety of concepts and technologies. To realize the overall concept, all products, machines, and other equipment as well as IT and production systems will have to work together intelligently using appropriate communication standards and interfaces. This connectivity is a critical factor for the realization of Industry 4.0. In particular, the connectivity through consistent machine-tomachine communication can only be achieved by introducing a standardized and manufacturer-independent syntax for processing as well as storing business, product, and production data [47].

In connection with that, the actors involved in Industry 4.0 have not yet managed to quickly agree on standards. In addition, the software architectures and business processes in many companies differ significantly from the processes outlined for Industry 4.0. In most of the available publications no attempt is made to close that gap. Furthermore, it is criticized that such a complex and non-linear system as a factory is not controllable with algorithms [49].

No matter how sophisticated algorithms may be, problems that require humaninnovative thinking (e.g., design problems) cannot be solved as easily as the automated operation of a machine. That is because the success of the elements of Smart Factories is mainly based on the experience, creativity and ability of their developers since machines and systems have a lack of cognition of practical circumstances. However, increasing hardware performance (e.g., memory and computing capacity) supports the realization of Smart Factories [50].

Additionally, it is criticized that there is little willingness to think outside the box of dayto-day business. Hence, one of the main purposes of Industry 4.0 is ignored, namely the establishment of new data-based business models. The problem is that their potential lies outside the factories. Accordingly, the mindset of actors in Industry 4.0 must go beyond the physical production environment and include the Digital Transformation [50].

It is stated that the Germans develop interfaces while the Americans create markets [49]. However, despite the understandable criticism, it must be noted that some industrial companies, are doing very well in this regard. Production companies today and, particularly, automotive manufacturers face global competition.

The markets are characterized by new dynamics due to volatile customer needs, increasing product variety and many other factors for that reason, the concept of Industry 4.0 emerged as a politically attempt to strengthen the international competitiveness of the German industry. That concept has international counterparts which also focus on the modernization of the production industry, while differing in some respects.

During the implementation of Industry 4.0, products, production equipment and even entire production environments are to be connected to one another $[54,55]$. However, criticism of the Industry 4.0 concept has also been expressed in the literature.

Among other things, the slow definition of standards and the currently prevailing mindset Concept of Industry 4.0in industrial companies are criticized. Nonetheless, it becomes clear that many of the criticisms are only partially valid. In addition, there is a consensus that the above-mentioned challenges can only be counteracted by adapted methods, concepts, and technologies, such as those provided by Industry 4.0. All things considered, Industry 4.0 results in dynamic, autonomous, and real-time optimized value chains that can be organized according to the market conditions and the resulting business models. Therefore, that requires cooperation between the technical and business components of companies, otherwise the potentials of Industry 4.0 cannot be fully exploited. 
In the literature there has been underlined the signs of the Industry 5.0 Revolution [56]. The transition is analyses from several years and it seems that pandemic period (2020 2021) has accelerated the digital transformation of the production systems and the society level, too.

\section{References}

1. T. Bauernhansl, Die Vierte Industrielle Revolution - Der Weg in einwertschaffendes Produktionsparadigma, in Industrie 4.0 in Produktion, Automatisierung und Logistik, (2014)

2. H.-J., Bullinger, et al., The American Journal of Philology, (2009)

3. E. Westkämper, E. Zahn, E. (Hrsg):Wandlungsfähige Produktionsunternehmen. Das Stuttgarter Unternehmensmodell. Berlin: Springer, (2009)

4. A.-W. Scheer, Die Welt wird flach - 20 Thesen zur Digitalisierung. IM+io Fachzeitschrift für Innovation, Organisation und Management, Heft 1/2016, S. 28 - 31, (2018)

5. Arbeitskreis Smart Service Welt / Acatech - Akademie der Technikwissenschaften (Hrsg.), Smart Service Welt - Umsetzungsempfehlungen für das Zukunftsprojekt Internetbasierte Dienste für die Wirtschaft. Abschlussbericht, Berlin, (2015)

6. D. Evans, Das Internet der Dinge - So verändert die nächste Dimension des Internet die Welt. Whitepaper, Cisco Internet Business Solutions Group (IBSG), April (2011). http://www.cisco.com/web/DE/assets/executives/pdf/Internet of Things_IoT IBSG 0 411FINAL.pdf(Accessed $5^{\text {th }}$ March 2021)

7. H. Kagermann, F. Riemensperger, D. Hoke, J. Helbig, D. Stockmeier, W. Wahlster, A.-W. Scheer, D. Schweer, Smart Service Welt - Umsetzungsempfeh-lungen für das Zukunftsprojekt Internetbasierte Dienste für die Wirtschaft, (2014)

8. T. Ramge, Mehr Ding als Internet - Alle reden von Industrie 4.0. Doch was steckt hinter dem Schlagwort? Eine Antwort in sechs Thesen. brand eins 7/2015, brand eins Verlag, Hamburg, S. 48 - 53, (2015)

9. PWC-Study, Industrie 4.0 - Chancen und Herausforderungen der vierten industriellen Revolution, 10/2014

10. S. Löbner, Semantik: Eine Einführung, De Gruyter Studienbuch, (2015)

11. M. Kröll, Methode zur Technologiebewertung für eine ergebnisorientierte Produktentwicklung, Jost-Jetter Verlag. University of Stuttgart, (2007)

12. M. Hermann, T. Pentek, B. Otto, Design Principles for Industrie 4.0 Scenarios: A Literature Review, TechnischeUniversitat Dortmund, (2015)

13. U. Sendler, Springer-Verlag, (2013)

14. H. Kagermann, W. Wahlster, J. Helbig, Umsetzungsempfehlung für das Zukunftsprojekt Industrie 4.0, Forschungsunion Wirtschaft und Wissenschaft, (2013)

15. D. Huber, T. Kaiser, Wie das Internet der Dinge neue Geschäftsmodelle ermöglicht, HMD Praxis der Wirtschaftsinformatik, (2015)

16. HPI,Nationaler IT-Gipfel, Hasso Plattner Institut, 2006.https:/hpi.de/veranstaltungen/wissenschaftliche-konferenzen/2006/1-nationaleritgipfel.html(Accessed: $1^{\text {st }}$ March 2021)

17. W. Becker, P. Ulrich, T. Botzkowski, Industrie 4.0 im Mittelstand: Best Practices und Implikationen für KMU, (2017)

18. W. Huber, Industrie 4.0 in der Automobilproduktion. Wiesbaden, (2016)

19. Bundesministerium für Wirtschaft und Energie (BMWi), Plattform Industrie 4.0, 2015. https://www.plattformi40.de/I40/Redaktion/DE/Kurzmeldungen/Aktuelles/2015/geschaeftsstelleneroeffnung. html(Accessed $5^{\text {th }}$ March 2021). 
20. BCMCOM,Industry 4.0 technologies for new trends and developments for industry delivering http://www.bcmcom.com/solutions application industry40 htm(Accessed $5^{\text {th }}$ March 2021)

21. V. P. Andelfinger, T. Hänisch, Industrie 4.0 Wie cyber-physische Systeme die Arbeitswelt verändern, Bundesministerium für Bildung und Forschung. Mosler, p. 4, (2017)

22. H. Lasi, et al., Industrie 4.0: Bedarfssog und Technologiedruck als Treiber der vierten industriellen Revolution, WIRTSCHAFTSINFORMATIK, 56(4), 261-264,2014

23. Gartner Inc., Digitization - Gartner IT Glossary, 2019. https://www.gartner.com/itglossary/digitization(Accessed $5^{\text {th }}$ March 2021)

24. Baumöl, U. and Jung, R., Rekursive Transformation: Entwicklung der Business Engineering-Landkarte, in. Springer Gabler, Berlin, Heidelberg, pp. 41-49, 2014

25. Becker, W., Eurich, S. and Botzkowski, P., Data Analytics in Familienunternehmen : Implikationen für das Controlling, 2015. https://opus4.kobv.de/opus4bamberg/frontdoor/index/index/year/2015/docId/26642(Accessed $6^{\text {th }}$ March 2021)

26. Kalinowski, T. and Verwaayen, E., DigITalisierung - quo vadis?, in Digitalisierung und Innovation. Wiesbaden: Springer Fachmedien Wiesbaden, pp. 485- 496, (2013)

27. H. Knoblauch, Die kommunikative Konstruktion der Wirklichkeit. Springer Fachmedien Wiesbaden (Neue Bibliothek der Sozialwissenschaften), (2016)

28. Plattform Industrie 4.0, What is Industrie 4.0?2019https://www.plattformi40.de/I40/Navigation/EN/Industrie40/WhatIsIndustrie 40/what-is-industrie40.html(Accessed $5^{\text {th }}$ March 2021).

29. acatech (2019) Akademie - acatech. Available at: https://www.acatech.de/akademie/ (Accessed: 5th March 2021).

30. Strehlitz, M., Digitale Fabrik und Industrie 4.0: Verbindung zweier Welten, 2016. https://www.automobil-produktion.de/iot-by-sap/iot-by-sap/verbindung-zweier-welten365.html(Accessed $6^{\text {th }}$ March 2021)

31. McKinsey \& Company, Manufacturing the future: The next era of global growth and innovation, 2012. https://www.mckinsey.com/ /media/McKinsey/Business Functions/Operations/Our Insights/The future of manufacturing/MGI Manufacturing_Fullreport_Nov 2012.ashx (Accessed $5^{\text {th }}$ March 2021)

32. P. Nyhuis, G. Reinhardt, E. Abele, Wandlungsfähige Produktionssysteme: Heute die Industrie von morgen gestalten. Garbsen: PZH Produktionstechnisches Zentrum, (2008)

33. S. Schlag, B. Runzheimer, Das Mercedes-Benz Produktionssystem (MPS), in Wiesbaden: Deutscher Universitätsverlag, (2001)

34. R. Diederichs, et al., Management: Applying Best-Practice Structures and Processes, in Abele, E. et al. (eds) Global Production: A Handbook for Strategy and Implementation. Berlin, Heidelberg: Springer Berlin Heidelberg, pp. 270-322, (2008)

35. V. Gupta, R. Ulrich, How the Internet of Things will reshape future production systems, 2017.https://www.mckinsey.com/business

functions/operations/ourinsights/how-the-internet-of-things-will-reshape-futureproduction-systems (Accessed $5^{\text {th }}$ March 2021)

36. A. Botthof, Zukunft der Arbeit in Industrie 4.0, (2014)

37. D. A. Elkins, N. Huang, J. M. Alden, Agile manufacturing systems in the automotive industry', International Journal of Production Economics, (2004)

38. P. Nyhuis, T. Heinen, M. Brieke, Adequate and economic factory transformability and the effects on logistical performance, International Journal of Flexible Manufacturing Systems, (2007) 
39. E. Abele, T. Liebeck, A. Wörn, Measuring flexibility in investment decisions for manufacturing systems, Manufacturing Technology

40. M. F. Zäh, W. Sudhoff, H. Rosenberger, Bewertung mobiler Produktionsszenarien mit Hilfe des Realoptionsansatzes, ZWF Zeitschrift für wirtschaftlichen Fabrikbetrieb, 98(12), pp. 646-651, (2003)

41. R. Cisek, C. Habicht, P. Neise, Gestaltung wandlungsfähiger Produktionssysteme, ZWF Zeitschrift für wirtschaftlichen Fabrikbetrieb. Carl Hanser Verlag, 97(9), pp. 441-445, (2002)

42. Y. Koren, General RMS Characteristics. Comparison with Dedicated and Flexible Systems, in Reconfigurable Manufacturing Systems and Transformable Factories. Berlin, Heidelberg: Springer Berlin Heidelberg, pp. 27-45, (2005)

43. H. P. Wiendahl, et al., Changeable Manufacturing - Classification, Design and Operation, CIRP Annals - Manufacturing Technology, (2007)

44. S. Hinrichsen, et al., Versatile assembly systems - requirements, design principles Bibliography 120 and examples, in Hochschule Ostwestfalen-Lippe: 4th International Conference Production Engineering and Management 2014. Proceedings : September 25 and 26, 2014, Lemgo, Germany.

45. H. A. ElMaraghy, H-P Wiendahl, Changeability - An Introduction, in Changeable and Reconfigurable Manufacturing Systems. London: Springer London, pp. 3-24, (2009)

46. A. Schumacher, P. Geissler, W. Sihn, Von smarten Technologien zur smarten Fabrik Die Basistechnologien der Industrie und deren Potential', WINGBusiness, (2016)

47. D. Siepmann, N. Graef, Industrie 4.0 - Grundlagen und Gesamtzusammenhang, in Einführung und Umsetzung von Industrie 4.0. Berlin, Heidelberg: Springer Berlin Heidelberg, pp. 17-82, (2016)

48. K-J. Meier, Lean QRM 4.0 - Das Beste aus Lean Production, QRM und Industrie 4.0 vereint in einem gemeinsamen Managementansatz, in Lean Production für die variantenreiche Einzelfertigung: Flexibilität wird zum neuen Standard. SpringerVerlag, pp. 119-135, ( 2017)

49. A. Syska, P. Liévre, Illusion 4.0: Deutschlands naiver Traum von der smarten Fabrik. CETPM Publishing, (2016)

50. P. Brödner, Industrie 4.0 und Big Data-wirklich ein neuer Technologieschub?, in Digitalisierung industrieller Arbeit. Nomos VerlagsgesellschaftmbH\& Co. KG, pp. 232-251, (2015)

51. A. Irniger, Difference between Digitization, Digitalization and Digital Transformation, 2017.https://www.coresystems.net/blog/difference-betweendigitization-digitalizationand-digital-transformation(Accessed $22^{\text {nd }}$ February 2021).

52. J. Bughin, E. Hazan, Labaye, Eric; Manyika, James; Dahlströhm, Peter; Ramaswamy, Sree; Cochin de Billy, Caroline, Digital Europe: Pushing the frontier, capturing the benefits. McKinsey Global Institute, 2016. https://www.mckinsey.com/businessfunctions/mckinsey-digital/our-insights/digital-europe-realizing-the-continentspotential(Accessed $5^{\text {th }}$ March 2021).

53. M. F. Zäh, N. Moeller, W. Vogl, Symbiosis of Changeable and Virtual Production The Emperor's New Clothes or Key Factor for Future Success?', International Conference on Changeable, Agile, Reconfigurable and Virtual Production, (2005)

54. J. Niemann, A. Pisla,Springer Nature, (2021)

55. J. Niemann, C. Fussenecker, M. Schlösser, E. Ocakci, The workers perspective -eye tracking in production environments. In Acta TechnicaNapocensis, Series Applied Mathematics, Mechnaics and Engineering, Vol 64, No 1 -S1, (2021)

56. D. Paschek, A. Mocan, A. Draghici, Proceedings of the MakeLearn and TIIM International Conference, (pp. 15-17), ( 2019) 